\title{
Field Losses of Coffee and Improved Harvesting Methods for Intensively Managed Plantations'
}

\author{
Servando Silva, José Vicente-Chandler, and Fernando Abruña ${ }^{2}$
}

\section{INTRODUCTION}

Many coffee plantations, intensively managed as recommended by Vicente-Chandler et al., ${ }^{3}$ are yielding up to 2,000 pounds of market coffee per acre. In these high-yielding fields many berries drop to the ground and are lost, yet there is little information available on the extent of these losses.

Coffee in much of Latin America is harvested by going over the plantations several times during the picking season, collecting only the ripe berries which are transferred to baskets tied to the pickers' waist. The berries are later processed by the wet method.

Little has been done to improve the efficiency of harvesting operations in intensively managed, high-yielding coffee plantations. Silva, Abruña, and Vicente-Chandler ${ }^{4}$ found that the number of pickings could be substantially reduced in intensively managed plantations, thus increasing labor efficiency.

The present study determined 1, total field losses of coffee beans under typical conditions in four intensively managed, high-yielding commercial plantations; 2, losses of berries occurring during actual picking operations; and 3, compared the efficiency of laborers harvesting coffee by the current method with that of laborers merely dislodging the ripe berries to fall on sections of plastic netting laid under the trees from where they were later collected for processing.

\section{MATERIALS AND METHODS}

The plantations studied are 8 to 10 years old and consistently yielding over 1,500 pounds of market coffee per acre yearly. Trees of the Bourbon

1 This paper covers work carried out cooperatively between the Soil and Water Conservation Research Division, Agricultural Research Service, USDA, and the Agricultural Experiment Station, Mayagüez Campus, University of Puerto Rico, both at Río Piedras, P.R.

- Agricultural Research Technician, Research Soil Scientist and Project Leader, and Research Soil Scientist, respectively, Soil and Water Conservation Research Division, Agricultural Research Service, USDA, stationed at Río Piedras, P.R.

'Vicente-Chandler, J., Abruña, F., Bosque-Lugo, R., and Silva, S., Intensive Coffee Culture in Puerto Rico, Bull. 211, Agr. Expt. Sta., Mayagüez Campus, Univ. P.R., 1968.

4 Silva, S., Abruña, F., and Vicente-Chandler, J., Effect of picking frequency on yields and quality of intensively managed coffee, J. Agr. Univ. P.R., 62 (4): 339-42, 1968. 
variety are planted 4 feet apart in rows 10 feet apart in full sunlight. The coffee trees have 2 to 4 vertical stems and are about 10 feet in height. Vegetative growth is dense (fig. 1), as would be expected of such highyielding plantations. Weeds are controlled by mowing or herbicide applications. The plantations are heavily fertilized and limed to $\mathrm{pH}$ 5.j. Coffee leaf-miners are controlled by annual applications of Disyston. Pruning is limited to the removal of old, dead, or broken branches.

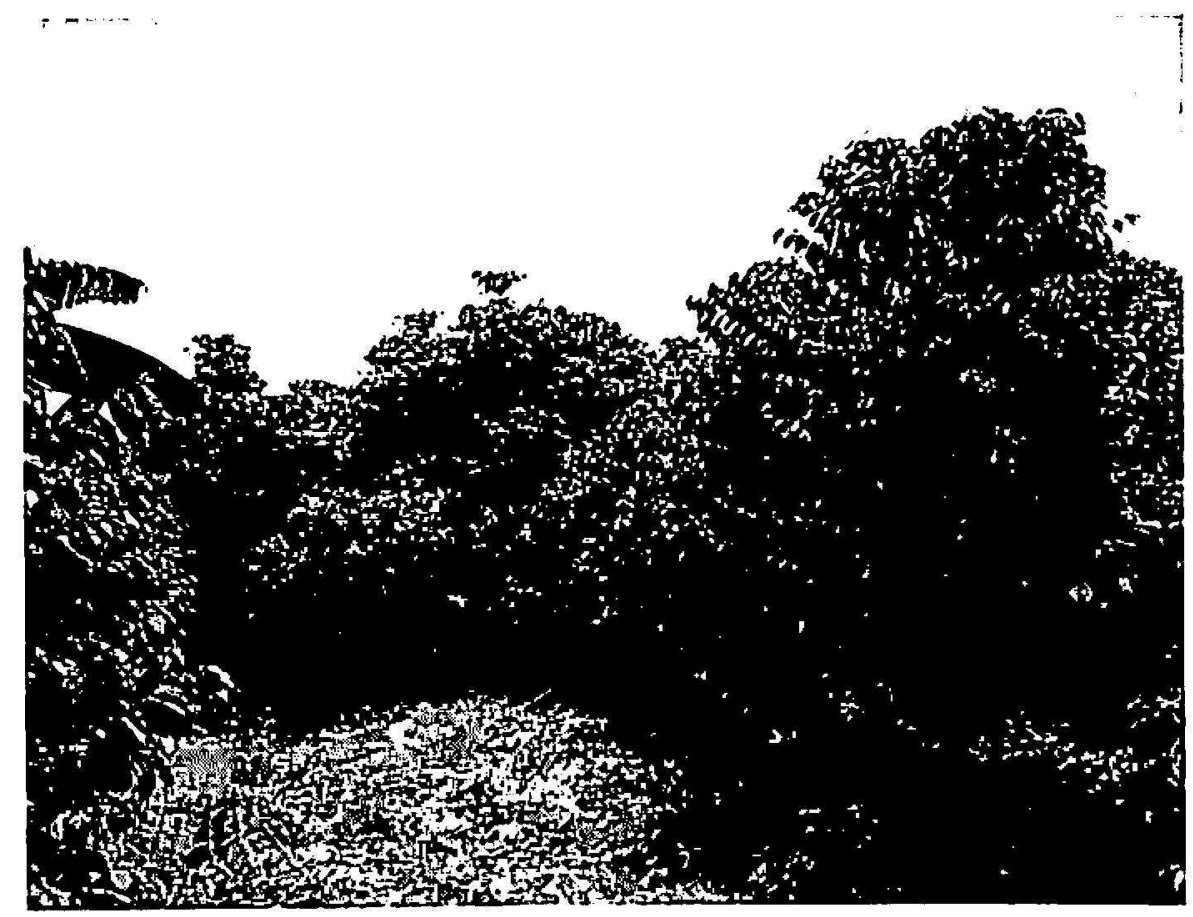

FIG. 1.-Eight-year-old, intensively managed coffee plantation near Aguas Buenas, showing massive growth in background which makes picking difficult and results in losses of berries falling to the ground equivalent to up to a third of the total crop. Dislodging coffee berries to fall on sections of light plastic netling laid on the ground ahead of the pickers as they move through the plantation rather than picking and placing the berries in baskets tied to the pickers waist as present reduces these losses and sharply increases efficiency of the laborers.

Field losses of coffee were determined in four plantations as follows: 1 , Ward Negros of Corozal, 15 acres at about 2,000 feet elevation; 2, Ward Cialitos of Ciales, 12 acres at about 2,000 feet elevation; 3, Ward Bayamoncito of Aguas Buenas, 15 acres at about 1,400 feet elevation; and 4, Ward Mameyes of Jayuya, 25) acres at about 2,000 feet elevation.

The study was conducted shortly after harvesting of the 1967 and 1968 crops was completed. All the plantations had been picked over 4 times during the harvest season, weather had been favorable, and a reasonable supply of laborers available.

Field losses of coffee beans were determined as follows: lour 50 foot $\mathrm{x}$ 50 foot areas were selected in each plantation and four 1 foot $x 1$ foot wire 
squares cast out in each, at random. Old seedlings and all leaves and trash were removed from these squares. Hard beans, and seedlings from the latest crop within each square were then counted. Calculations from these data provide an estimate of the coffee beans lost in the field during the 1967 and 1968 crop-years. It was assumed that 1 pound of market coffee contains 2,500 beans.

The study of losses of coffee beans resulting directly from picking operations was carried out at the Aguas Buenas farm at the height of the 1968 picking season. Six 12 -foot $\times 2$ 25-foot sections of plastic netting were spread at random on the ground throughout the plantation. A laborer was assigned to pick all the ripe berries on the coffee branches above each section of netting. Weight of berries picked and of those falling on the netting in

T.। HLE 1.-Field losses of coffee beans, expressed in pounds of market coffee per acre, in 4 inlensively-managed commercial planlations during the 1967 and 1968 harvest seasons

\begin{tabular}{|c|c|c|c|c|c|c|c|c|}
\hline \multirow{3}{*}{ Site No. } & \multicolumn{8}{|c|}{ Location of plantation and date } \\
\hline & \multicolumn{2}{|c|}{$\begin{array}{l}\text { Ward Negros } \\
\text { Corozal }\end{array}$} & \multicolumn{2}{|c|}{$\begin{array}{l}\text { Ward Cialitos } \\
\text { Ciales }\end{array}$} & \multicolumn{2}{|c|}{$\begin{array}{c}\text { Ward Bayamoncito } \\
\text { Aguas Buenas }\end{array}$} & \multicolumn{2}{|c|}{$\underset{\text { Jayuya }}{\text { Ward Mameyes }}$} \\
\hline & 1967 & 1958 & 1967 & 1968 & 1967 & 1968 & 1967 & 1968 \\
\hline 1 & 887 & 945 & 1,427 & 1,020 & 1,044 & 1,080 & 922 & 930 \\
\hline 2 & 887 & 991 & 557 & 1,070 & 878 & 1,120 & 1,096 & 710 \\
\hline 3 & 557 & (j)5 & 592 & 750 & 791 & 1,100 & 870 & 920 \\
\hline 4 & 1,079 & 1,100 & 748 & 940 & 696 & 1,200 & 1,027 & 1,170 \\
\hline Average & 852 & 925 & 831 & 945 & 852 & 1,127 & 979 & 935 \\
\hline
\end{tabular}

each section were determined, as was the proportion of green berries falling on the netting.

The study comparing picking efficiency of laborers harresting coffee by the usual method of using baskets with that of pickers dislodging ripe berries to fall on netting laid under the trees, was also conduced at the Agua Buenas farm at the height of the 1968 harvest season. Laborers were assigned to pick coffee for half an hour each, alternating both methods, and the amount of coffee harvested in each case determined. Quantity of green berries was determined in all cases where netting was used.

\section{RRGULTS A.ND DISCUSSIOX}

Table 1 shows that an arerage of 931 pounds of market coffee, worth over $\$(600$, were lost per acre rearly on these four typical, intensively managed coffee plantations. There was surprisingly little variation in losses of coffee beans in these widely separated plantations.

These high losses of coffee explain why carefully harested experimental 
areas consistently yield 2,500 pounds or more of market coffee per acre, whereas commercial plantations with similar intensive management yield only 1,500 to 2,000 pounds.

This heavy loss of coffee beans averaging $\$ 600$ per acre, in addition to picking costs of about $\$ 400$ for a 2,000-pound crop, leave a margin wide enough to justify drastic changes to increase the efficiency of present harvesting operations.

Table 2 shows that about 12 percent of the ripe berries fall to the ground during actual picking operations in high-yielding coffee plantings. Considerable quantities of green berries are dislodged in picking larger, densely growing coffee trees. Although losses of coffee as green berries are small, these should be separated from the ripe berries before processing.

TABLE 2.-Coffee berries lost by dropping to the ground during actual picking operations in a high-yielding coffee plantalion during one picking at the height of the 1968 harvest season

\begin{tabular}{c|c|c|c}
\hline Replicate & $\begin{array}{c}\text { Ripe berries } \\
\text { picked per acre }\end{array}$ & $\begin{array}{c}\text { Ripe berries dropped } \\
\text { on netting per acre }\end{array}$ & $\begin{array}{c}\text { Green berries dropped } \\
\text { on netting per acre }\end{array}$ \\
\hline & Poutrds & Pounds & Pounds \\
A & 2,550 & 252 & 5 \\
B & 3,906 & 300 & 4 \\
C & 6,048 & 636 & 17 \\
D $^{*}$ & 3,024 & 336 & 85 \\
E $^{*}$ & 4,032 & 672 & 85 \\
F $^{*}$ & 3,360 & 840 & 170 \\
\hline Average & 3,820 & 506 & 61 \\
\hline
\end{tabular}

* Area of larger coffee trees.

These data indicate that about 200 pounds of market coffee can be recovered per acre yearly in high-yielding plantations, by providing pickers with sections of netting to lay on the ground as they move through the plantation picking the ripe berries. The pickers must separate all green berries from the ripe ones, but would be paid at current prices of $\$ 1.00$ per 5 gallons of berries or about 20 cents per pound of market coffee for the berries recovered from the netting.

Benefit to the farmer of such a system would be approximately as follows:

200 pounds of market coffee recovered $x 68$. $\ldots \ldots \ldots \ldots \ldots \ldots \ldots \ldots \ldots \ldots 136$

Minus (1) Picking costs (20\& per pound) $\ldots \ldots \ldots \ldots \ldots \ldots \ldots \ldots \ldots \ldots \ldots \ldots \$ 40$

(2) Processing and other handling costs $(4 \&$ per pound) $\ldots \ldots \ldots \ldots \ldots \$ 8$

(3) 500 sq. ft. of netting at $1 \&$ per $\mathrm{sq}$ foot, depreciated over 5 years.....\$ 1

Net profit per acre yearly 
Table 3 shows that, in all cases, laborers harvested much more coffee by dislodging the berries to fall on netting laid on the ground than by the usual method of placing picked berries in baskets tied to their waists. This simple method of harvesting coffee could increase pickers' income by over 50 percent. Farmers, in turn, would benefit by not losing the 12 percent or so of berries currently dropping to the ground during actual picking operations (table 2). Also, since the efficiency of available pickers would be increased by about 50 percent, less coffee would be lost because of scarcity of laborers during critical periods.

Table 3 shows that an average of 6.3 percent of the berries falling on the netting were green, about $1 / 3$ of these were immature. Green berries should

TABLE 3.-Picking efficiency of laborers harvesting ripe berries transferred to a basket al their waists compared to dislodging berries onlo netting laid on the ground

\begin{tabular}{c|c|c|c}
\hline \multirow{2}{*}{ Replicate } & \multicolumn{2}{|c|}{ Ripe berries picked over a 36-hour period } & $\begin{array}{c}\text { Green berries } \\
\text { falling on } \\
\text { netting }\end{array}$ \\
\cline { 2 - 3 } & Baskets & Netting & \\
\hline & Pounds & Pounds & Pounds \\
A & 9.0 & 12.4 & 0.6 \\
B & 7.8 & 14.3 & .9 \\
C & 6.7 & 12.4 & .9 \\
D & 8.8 & 16.5 & 1.4 \\
E & 10.0 & 14.0 & .6 \\
F & 9.8 & 19.5 & .9 \\
G & 9.8 & 12.0 & .9 \\
H & 16.0 & 18.7 & 1.4 \\
& 9.74 & 14.97 & 0.95 \\
\hline
\end{tabular}

be separated from the ripe ones before processing. Considerable green berries are also picked along with the ripe in the conventional system of harvesting.

Observations made during these studies indicate that netting should be of light plastic, available on the market at about 1 cent per square foot. Sections for each laborer should be about 15 feet in length and about 2 feet wider than the coffee rows. In this way the netting can be laid up against the lower row of coffee trees to catch berries rolling downhill. The few leaves falling on the netting can be easily removed by hand in the field.

\section{SUMMARY}

Total field losses of coffee beans in four 8- to 10-year-old intensivelymanaged commercial plantations consistently yielding over 1,500 pounds of picked market coffee per acre, averaged 931 pounds of market coffee worth over $\$ 600$ per acre during the 1967 and 1968 crop years. 
An average of 12 percent of the total ripe berries produced are lost by dropping to the ground during actual picking operations. Strips of plastic netting laid on the ground under the trees during harvesting could recover this coffee (over 200 pounds of a 2,000-pound crop) with a net benefit to the farmer of about $\$ 87$ per acre yearly.

Laborers harvested about 50 percent more coffee by dislodging ripe berries to fall on netting laid on the ground than by the usual method of placing picked berries in baskets tied to their waists. This simple method could increase the pickers' income and reduce losses of beans falling to the ground during picking. It would also reduce losses of coffee due to labor shortages during critical periods in the picking season by increasing the efficiency of the available laborers.

\section{RESUMEN}

Las pérdidas de café en el campo, en cuatro siembras comerciales bajo cultivo intensivo, con cosechas de más de 1,500 libras de café pilado por cuerda, alcanzaron un promedio de 931 libras de café pilado por cuerda anualmente, valoradas en más de $\$ 600$.

Un promedio de 12 por ciento (approximadamente 200 libras por cuerda) del total de café maduro producido, se perdió al caer al suelo como resultado directo de la recolección. El uso de trozos de mallas plásticas para tenderse en el suelo durante la cogida y así recobrar este café caído, resulta en una ganancia neta para el agricultor de alrededor de $\$ 87$ por cuerda anualmente, en plantaciones cultivadas intensivamente.

Los obreros cosecharon un $\mathbf{5 0}$ por ciento más de café cuando se limitaron a desprender las uvas maduras para que cayeran en trozos de malla plástica tendidas en el suelo, que cuando recogieron el café por el método corriente usando canastas. Este método sencillo de cosechar café puede aumentar el ingreso de los obreros, a la vez que beneficia al agricultor, pues asi no pierde el café que cae al suelo durante la cogida. Además, se perdería menos café por falta de obreros ya que los pocos que haya disponibles podrían coger más café. 